\title{
DETERMINING LEAD ACTIVITY IN AN EGYPTIAN ALLUVIAL SOIL USING COMPETITIVE CHELATION METHOD
}

\author{
Samer A. El-Gendi ${ }^{1 *}$, M.A. Hassan ${ }^{1}$ and E.A. El-Naka ${ }^{2}$ \\ 1. Soils Water and Environ. Res. Inst., Egypt \\ 2. Soil Sci. Dept., Fac. Agric., Zagzig Univ., Egypt
}

Received: 04/04/2017 ; Accepted: 30/05/2017

\begin{abstract}
Lead has been emitted into atmosphere since the birth of metallurgy in ancient times and with increasing intensity since the establishment of medieval and modern industries. In the present study lead activity was measured in six alluvial soil samples which were collected from 6 successive layers (15-cm thick, each) from surface soil to $90 \mathrm{~cm}$ depth to identify the various $\mathrm{Pb}$ minerals which might control $\mathrm{Pb}$ activities in that soils (using constructed lead stability mineral diagrams). The $\mathrm{Pb}$ content decreased with increasing soil depth, ranging from $20.50 \mathrm{\mu gg}^{-1}$ in the surface layer to 11.03 $\mathrm{ugg}^{-1}$ in the deepest soil sample, which mostly reflect the impact of anthropogenic influences on leadcontamination in soil. The values of $\log \mathrm{Pb}^{2+}$ activities varied from -4.9498 to -7.1098 and were inversely correlated with $\mathrm{pH}$. The predicted relationship equation could be: $\log \left(\mathrm{Pb}^{2+}\right)=9.619-2.111$ $(\mathrm{pH})$, indicating that lead solubility in soil decreased about 100 folds for each $\mathrm{pH}$ unit increase. Plotting $\mathrm{Pb}$ activities on the constructed stability diagram of various $\mathrm{Pb}$ minerals indicated the solubility of $\mathrm{PbO}$ being too soluble to persist under normal conditions . $\mathrm{Pb}_{2} \mathrm{SiO}_{4}$ and $\mathrm{PbSiO}_{3}$ minerals in equilibrium with $\mathrm{SiO}_{2}$ (soil) or $\mathrm{SiO}_{2}$ (quartz) were too soluble to regulate $\mathrm{Pb}^{2+}$ activities. $\mathrm{Pb}_{5}\left(\mathrm{PO}_{4}\right)_{3} \mathrm{Cl}$ was the most insoluble of lead phosphate minerals and controls lead solubility throughout $\mathrm{pH}$ range of most soils. Values of $\mathrm{Pb}^{2+}$ were lower than those maintaining by $\mathrm{Pb}_{5}$ $\left(\mathrm{PO}_{4}\right)_{3}$. $\mathrm{OH}$ mineral. $\mathrm{Pb}$ - mixed carbonate and hydroxide minerals indicating that $\mathrm{PbCO}_{3} . \mathrm{PbO}$, was too soluble to persist. Values of $\mathrm{Pb}^{+2}$ were super saturated with respect of $\mathrm{Pb}(\mathrm{OH})_{2}, \mathrm{PbCO}_{3}$ and $\mathrm{Pb}_{3}\left(\mathrm{CO}_{3}\right)_{2}(\mathrm{OH})_{2}$ at 0.0003 atm. $\mathrm{CO}_{2}$. In presence of $10^{-3} \mathrm{M} \mathrm{SO}_{4}, \mathrm{PbSO}_{4}$ mineral limits $\mathrm{Pb}$ at $10^{-4.79} \mathrm{M}$ and its solubility changes one log unit per each log unit change in $\mathrm{SO}_{4}{ }^{-2}$. In the high-lead surface soil sample $\mathrm{Pb}^{+2}$ activity values were maintained by $\mathrm{PbSO}_{4} \cdot \mathrm{PbO}$ and $\mathrm{PbSO} 4\left(\log \mathrm{SO}_{4}\right.$ at -2 ), confirming the importance of studying environmental chemistry of the heavy metals.
\end{abstract}

Key words: Lead, activity, chelation, stability diagram, Pb-minerals.

\section{INTRODUCTION}

Daunting challenges of Egypt are the problems, resulting from human activities, such as fast unbalanced population growth, undernourishment, unplanned urbanization, adverse land use, dangerous and harmful wastes (El-Gendi et al., 1997; Badawy and El-Motium, 2002; Abd ElAziz, 2014), unconscious energy consumption, heavy metal contamination created by industrial wastes (Esawy and Adel Mohamed, 2016) and from traffic emission (El-Gendi, 1994; Ahmed et al., 2015). The majority of the heavy metals are toxic to the living organisms and even those considered as essential can be toxic if present in excess. The heavy metals can impair important biochemical processes posing a threat to human health, plant growth and animal life (KabataPendias and Pendias, 1992; Chibuike and Obiora, 2014).

Lead is widespread in the environment. This toxic element has been emitted into atmosphere since the birth of metallurgy in ancient times and with increasing intensity since the

* Corresponding author: Tel. : +201001992635

E-mail address: samir_elgendi@yahoo.com 
establishment of medieval and modern industries (Settle and Patterson, 1980; Sripathy et al., 2015). It has been established that in most circumstances, the concentration as well as the activity of free metal ions is the key factor in determining metal bioavailability and toxicity (Alloway, 1995; Candelaria et al., 1995). The ion activity of trace metals can be used in thermodynamics to describe the direction and impetus of chemical reactions such as precipitation, complexation and adsorption (Santillan-Medrano and Jurinak, 1975). There are several approaches that have been widely used to determine the free ion concentration (activity). Each method has its advantages and limitations. The electrochemical method of ion selective electrode (ISE) potentiometry is one of the most powerful methods in speciation studies because the activity of free metal ion is measured directly (Mota and Correia dos Santos, 1995). The voltammetric electrochemical methods such as anodic stripping voltammetry (ASV) and adsorptive cathodic stripping voltammetry (ACSV) provide the most direct methods for the study of trace metal speciation in low concentrations. The competitive chelation method has good sensitivity and provides estimates of ion activities (Amacher, 1984). However, chelates attain equilibrium with soils very slowly (Norvell and Lindsay, 1982; Workman and Lindsay, 1990). Accuracy of the competitive chelation method depends on the reliable estimation of chelated metal contents and reference ion concentration. The method can be successful only if the metal of interest and the selected competing metal are the principal chelated metals (Workman and Lindsay, 1990). Therefore, the main objectives of the present work were to determine the active portion of $\mathrm{Pb}$ in alluvial soils and to identify its various solid phases in these soils along with knowledge of their solubility and kinetic of dissolution and precipitation using stability diagrams.

\section{MATERIALS AND METHODS}

Samples from Six layers from an alluvial soil from El-Kanater Horticulture Research Station (25 Km from Cairo) were taken. From each layer one composite soil sample was collected successively (at 15-cm thickness from surface layer to $90 \mathrm{~cm}$ depth) with a contention that deepest layer would be the least exposed to $\mathrm{Pb}$ pollution. By this way six soil samples varying in $\mathrm{Pb}$ concentration were obtained. Main properties of the tested soils were determined by (Chapman and Pratt, 1961; Black, 1965) and listed in Table 1.

Soil $\mathrm{pH}$ was measured in $1: 2$ soil: water ratio using $0.01 \mathrm{M} \mathrm{CaCl}_{2}$ as background solution to dimension the influence of ionic strength inference among the tested samples as described by Lindsay and Norvall (1978).

$\mathrm{Pb}^{+2}$ activity was measured using the competitive chelation method given in details by El-Gendi (1994). This method depends on reacting soil with a series of chelate solution having different mole fractions of $\mathrm{Pb}$ and $\mathrm{a}$ competing $\mathrm{Cd}$ metal. A series of chelating solutions, having different mole fractions of chelate ligand $(\mathrm{L})$, that is $(\mathrm{PbL} / \mathrm{PbL}+\mathrm{CdL})$, were prepared using reagent grade diethylene triaminepentaacetic acid (DTPA), $\mathrm{Pb}\left(\mathrm{NO}_{3}\right)_{2}$ and $\mathrm{Cd}\left(\mathrm{NO}_{3}\right)_{2}$. The initial $\mathrm{PbL} /(\mathrm{PbL}+\mathrm{CdL})$ mole fractions used varied from 0.0 to 0.3 and included five to ten different mole fractions. The DTPA concentration was fixed at $100 \mu \mathrm{M}$ in all cases.

Fifteen-gram subsamples of each soil were weighed in $125 \mathrm{ml}$ Erlenmeyer flasks, and $30 \mathrm{ml}$ of $0.01 \mathrm{M}$ of $\mathrm{CaCl}_{2}$ solution having a given $\mathrm{PbL} /(\mathrm{PbL}+\mathrm{CdL})$ mole fraction was added along with $10 \mathrm{mg}$ of $\mathrm{CdCO}_{3}$ to maintain a known $\mathrm{Cd}^{2+}$ activity in the solution. For each soil, a blank treatment without a chelating agent was prepared by shaking $15 \mathrm{~g}$ of soil with $30 \mathrm{ml}$ of $0.01 \mathrm{M} \mathrm{CaCl}{ }_{2}$ solution. The Erlenmeyer flasks were then covered with perforated parafilm to allow gas exchange with the atmosphere. The suspensions were shaken for 5 days, after which $\mathrm{pH}$ was measured, then centrifuged, filtered and the clear supernatant were analyzed for $\mathrm{Pb}$ and Cd using atomic absorption spectrophotometer.

\section{Calculation}

The final mole fraction of $\mathrm{Pb} /(\mathrm{PbL}+\mathrm{CdL})$ for each soil was calculated from the total soluble $\mathrm{Pb}$ and $\mathrm{Cd}$ after subtracting $\mathrm{Pb}$ and $\mathrm{Cd}$ in the $\mathrm{CaCl}_{2}$ blank treatment. A graph relating initial and final $\mathrm{PbL} /(\mathrm{PbL}+\mathrm{CdL})$ mole fractions was made for each soil, and the equilibrium $\mathrm{PbL} /(\mathrm{PbL}+\mathrm{CdL})$ mole fractions were obtained Fig.1, which was used to calculate $\mathrm{Pb}^{2+}$ activity in the soil. 
Zagazig J. Agric. Res., Vol. 44 No. (4) 2017

Table 1. Main properties of the investigated soil samples

\begin{tabular}{|c|c|c|c|c|c|c|}
\hline \multirow[t]{2}{*}{ Soil characteristics } & Sample 1 & Sample 2 & Sample 3 & Sample 4 & Sample 5 & Sample6 \\
\hline & \multicolumn{6}{|c|}{$(0-15 \mathrm{~cm})(15-30 \mathrm{~cm})(30-45 \mathrm{~cm})(45-60 \mathrm{~cm})(60-75 \mathrm{~cm})(75-90 \mathrm{~cm})$} \\
\hline$\overline{\mathbf{p H}}$ & 07.12 & 07.35 & 07.24 & 07.36 & 07.30 & 07.37 \\
\hline $\left.\mathrm{EC}(\mu \mathrm{s} \mathrm{cm})^{-1}\right)$ & 01.37 & 01.46 & 01.41 & 01.38 & 01.42 & 01.43 \\
\hline $\mathrm{CEC}\left(\mathrm{Cmol}_{\mathrm{c}} \mathrm{Kg}^{-1}\right.$ soil $)$ & 44.15 & 40.28 & 36.10 & 35.21 & 37.25 & 36.18 \\
\hline Organic matter $\left(\mathrm{gKg}^{-1}\right)$ & 25.40 & 21.50 & 18.20 & 15.60 & 17.10 & 16.50 \\
\hline $\mathrm{CaCO}_{3}\left(\mathrm{gKg}^{-1}\right)$ & 18.70 & 19.10 & 12.60 & 14.30 & 11.20 & 10.90 \\
\hline Total Pb $\left(\mu g g^{-1}\right)$ & 20.05 & 16.71 & 12.70 & 11.43 & 11.26 & 11.03 \\
\hline Available Pb $\left(\mu \mathrm{gg}^{-1}\right)$ & 01.59 & 01.31 & 01.42 & 01.37 & 0.94 & 01.02 \\
\hline
\end{tabular}

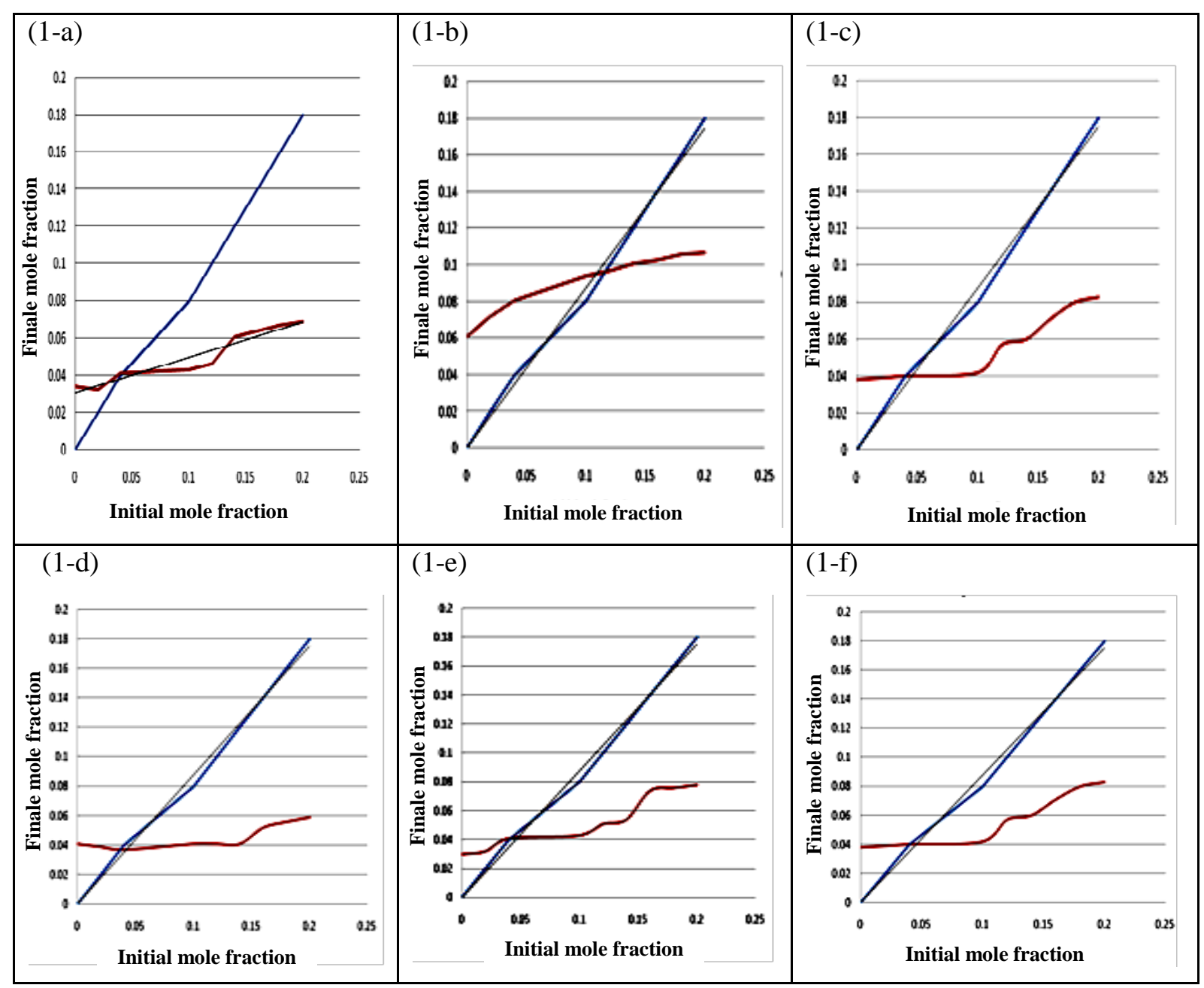

Fig. 1. Changes in $\mathrm{CdL} /(\mathrm{CdL}+\mathrm{PbL})$ mole fraction in the tested soil samples 
Derivation of the equilibrium equation used to calculate $\mathrm{Pb}^{+2}$ activity is given as follows:

$\log { }^{m}{ }_{0.01}$

$\mathrm{PbL}^{3-}===========\mathrm{Pb}^{2}++\mathrm{L}^{5-}-19.93$

$\mathrm{Cd}^{2}++\mathrm{L}^{5-}=====$ CdL3- +20.27

$\mathrm{PbL}^{3-}+\mathrm{Cd}^{2+}=====\mathrm{Pb}^{2+}+\mathrm{CdL}^{3-}+0.34$

Where:

$\mathrm{k}_{\mathrm{m}}$ is the mixed equilibrium constant expressed in terms of concentration, except for $\mathrm{H}^{+}, \mathrm{OH}^{-}$, and $\mathrm{e}^{-}$which, if present, are expressed as activities (Lindsay, 1979), $\mathrm{L}^{5-}$ is the concentration of free DTPA, and [ ] indicate molar concentrations.

Rearranging Eq. 3; gives :

$\left[\mathrm{Pb}^{2+}\right]=\left[\mathrm{PbL}^{3-}\right] /\left[\mathrm{CdL}^{3-}\right] \times 10^{0.34} \times\left[\mathrm{Cd}^{2+}\right]----(4)$

Since the activity coefficients of $\mathrm{Pb}^{2+}, \mathrm{Cd}^{2+}$ $\mathrm{PbL}^{2+}$ and $\mathrm{CdL}^{3-}$ are equal; Equation 4 can be written in terms of activities, as follows:

$\left(\mathrm{Pb}^{2+}\right)=\left(\mathrm{PbL}^{3-}\right) /\left(\mathrm{CdL}^{3-}\right) \times 10^{0.34} \times\left(\mathrm{Cd}^{2+}\right)----(5)$

Inputs to eq. (5) include $\left(\mathrm{PbL}^{3-}\right) /\left(\mathrm{CdL}^{3-}\right)$ and $\left(\mathrm{Cd}^{2+}\right)$. Values for $\left(\mathrm{PbL}^{3-}\right) /\left(\mathrm{CdL}^{3-}\right)$ were obtained from the measured $\left[\mathrm{Pb}^{2+}\right]=\left[\mathrm{PbL}^{3-}\right] /\left[\mathrm{CdL}^{3-}\right]$ obtained for each soil .

Since $\mathrm{CdCO}_{3}$ was added to the soil suspensions to control $\mathrm{Cd}^{2+}$ activity throughout the experiment and the solutions were open to atmospheric $\mathrm{CO}_{2}, \mathrm{Cd}^{2+}$ activity was obtained according to Lindsay (1979) as follows:

$\mathrm{CdCO}_{3}(\mathrm{C})+2 \mathrm{H}+====\mathrm{Cd}^{2+}+\mathrm{CO} 2(\mathrm{~g})+\mathrm{H}_{2} \mathrm{O}$ $\operatorname{LogK}^{0} 6.16$

$\left(\mathrm{Cd}^{2+}\right)=10^{6.16} *\left(\mathrm{H}^{+}\right)^{2} / \mathrm{CO}_{2}$, at $0.003 \mathrm{~atm} . \mathrm{CO}_{2}$

Hence, $\left(\mathrm{Cd}^{2+}\right)=10^{9.68} *\left(\mathrm{H}^{+}\right)^{2}$

Substituting Eq. 8 into Eq. 5 gives:

$\left(\mathrm{Pb}^{2+}\right)=(\mathrm{PbL}) /(\mathrm{CdL}) * 10^{(10.02-2 \mathrm{pH})}$.

The $\mathrm{pH}$ value used in Eq.9 was the $\mathrm{pH}$ of the suspension closest to the equilibrium point in the initial and final mole fraction plot.

\section{Stability Diagrams}

Lead minerals that may control the level of $\mathrm{Pb}^{2+}$ in soils were plotted on an equilibrium solubility diagram in terms of $\mathrm{Pb}^{2+}$ activity and $\mathrm{pH}$ (Fig. 3) using the thermodynamic data in
Table 2 taken from Lindsay (1979) to calculate the equilibrium relationships in the following manner;

$$
\begin{aligned}
\mathrm{PbCO}_{3(\mathrm{c})}+2 \mathrm{H}^{+}=== & =\mathrm{Pb}^{2+}+\mathrm{CO}_{2(\mathrm{~g})}+\mathrm{H}_{2} \mathrm{O} \quad 4.65(\mathrm{Log} \\
\left.\mathrm{K}^{0}\right) & \\
\log \mathrm{Pb}^{2+} & =4.65-\mathrm{Log} \mathrm{CO}_{2}-2 \mathrm{pH}
\end{aligned}
$$

At $\mathrm{CO}_{2}=0.0003 \mathrm{~atm}$, this equation becomes;

$$
\log \mathrm{Pb}^{2+}=8.17-2 \mathrm{pH}
$$

At $\mathrm{CO}_{2}=0.003 \mathrm{~atm}$, this equation becomes ;

$$
\text { Log } \mathrm{Pb}^{2+}=7.17-2 \mathrm{pH}
$$

The remaining minerals were plotted in same manner, meanwhile lead silicate minerals were depicted in equilibrium with $\mathrm{SiO}_{2}$ (soil) and $\mathrm{SiO}_{2}$ (quartz). Lead phosphate minerals were depicted in equilibrium various phosphate minerals which in turn depend on level of $\mathrm{CaCO}_{3}$ which in turn controlled by $\mathrm{CO}_{2}$ partial pressure.

\section{RESULTS AND DISCUSSION}

A plot of the final $\mathrm{PbL} /(\mathrm{PbL}+\mathrm{CdL})$ mole fraction of the filtrates against the initial mole fractions are presented from Figs. (1a to 1f). The intersected between them pointed out to the equilibrium point, where the soil sample neither gain nor loss of $\mathrm{Pb}$. This equilibrium value was used in the following equation to calculate $\mathrm{Pb}$ activities by using the following formula; and the results are listed in Table 2.

$$
\left(\mathrm{Pb}^{2+}\right)=(\mathrm{PbL}) /(\mathrm{CdL}) * 10^{(10.02-2 \mathrm{pH})}
$$

It is clear from the Figs that at low concentrations of initial mole fraction; $\mathrm{Pb}$ released from the soil sample to the equilibrium solution, whereas at high concentrations; the chelate lost $\mathrm{Pb}$.

As shown in Table 3 the values of $\log \mathrm{Pb}^{2+}$ activity varies widely among the tested soil samples; being from -4.9498 to -7.1098. Log $\mathrm{Pb}$ activity increased with increasing available $\mathrm{Pb}(\mathrm{r}$ of 0.970 , highly significant correlation).

On the other hand, as shown in Fig 2 the correlation between logarithmic $\mathrm{Pb}^{2+}$ activity and soil $\mathrm{pH}$ being very highly significant correlated $(\mathrm{r}=-0.997)$ and the predicted equation is; 
Log $\mathrm{Pb}^{2+}=9.619-2.111(\mathrm{pH})$

Table 2. The equilibrium activity constants $\left(\mathrm{k}^{0}\right)$ of some lead minerals

\begin{tabular}{lc}
\hline Equilibrium reaction & Log $\mathbf{K}^{\mathbf{0}}$ \\
\hline $\mathrm{Pb}(\mathrm{OH})_{2}+2 \mathrm{H}^{+}===========$ & 8.16 \\
$\mathrm{PbCO}_{3}+2 \mathrm{Hb}^{+}===========\mathrm{Pb}^{2+}+\mathrm{CO}_{2}(\mathrm{~g})+\mathrm{H}_{2} \mathrm{O}$ & 4.65 \\
$\mathrm{~Pb}_{3}\left(\mathrm{CO}_{3}\right)_{2}(\mathrm{OH})_{2}+6 \mathrm{H}+======3 \mathrm{~Pb}^{2+}+2 \mathrm{CO}_{2}+4 \mathrm{H}_{2} \mathrm{O}$ & 17.51 \\
$\mathrm{PbCO}_{3} \cdot \mathrm{PbO}_{\odot}+4 \mathrm{H}+========2 \mathrm{~Pb}^{2+}+\mathrm{CO}_{2}+2 \mathrm{H}_{2} \mathrm{O}$ & 17.39 \\
$\mathrm{PbSiO}_{3}+2 \mathrm{H}^{+}+\mathrm{H}_{2} \mathrm{O}========\mathrm{Pb}^{2+}+\mathrm{H}_{4} \mathrm{SiO}_{4}$ & 5.94 \\
$\mathrm{~Pb}_{2} \mathrm{SiO}_{4}+4 \mathrm{H}^{+}===========2 \mathrm{~Pb}^{2+}+\mathrm{H}_{4} \mathrm{SiO}_{4}$ & 18.45 \\
$\mathrm{PbHPO}_{4}+\mathrm{H}^{+}=============\mathrm{Pb}^{2+}+\mathrm{H}_{2} \mathrm{PO}_{4}$ & -4.52 \\
$\mathrm{~Pb}_{3}\left(\mathrm{PO}_{4}\right)_{2}+4 \mathrm{H}^{+}==========3 \mathrm{~Pb}^{2+}+2 \mathrm{H}_{2} \mathrm{PO}_{4^{-}}$ & -5.26 \\
$\mathrm{~Pb}_{4} \mathrm{O}\left(\mathrm{PO}_{4}\right)_{2}+6 \mathrm{H}^{+}=========4 \mathrm{~Pb}^{2+}+2 \mathrm{H}_{2} \mathrm{PO}_{4^{-}}+\mathrm{H}_{2} \mathrm{O}$ & 2.24 \\
$\mathrm{~Pb}_{5}\left(\mathrm{PO}_{3}\right)_{3} \mathrm{OH}+7 \mathrm{H}^{+}========5 \mathrm{~Pb}^{2+}+3 \mathrm{H}_{2} \mathrm{PO}_{4}+\mathrm{H}_{2} \mathrm{O}$ & -4.14 \\
$\mathrm{SiO}_{2}(\mathrm{soil})+2 \mathrm{H}_{2} \mathrm{O}==========\mathrm{H}_{4} \mathrm{SiO}_{4}$ & -3.10 \\
$\mathrm{SiO}_{2}\left(\mathrm{quartz}+2 \mathrm{H}_{2} \mathrm{O}=======\mathrm{H}_{4} \mathrm{SiO}_{4} \mathrm{O}\right.$ & -4.00 \\
$\mathrm{CaCO}_{3}+2 \mathrm{H}^{+}==============\mathrm{Ca}^{2+}+\mathrm{CO}_{2}+\mathrm{H}_{2} \mathrm{O}$ & 9.74 \\
$\mathrm{CaHPO}_{4} \cdot 2 \mathrm{H}_{2} \mathrm{O}+\mathrm{H}^{+}==========\mathrm{Ca}^{2+}+\mathrm{H}_{2} \mathrm{PO}_{4^{-}}+2 \mathrm{H}_{2} \mathrm{O}$ & 0.63 \\
$\left(\mathrm{Ca}_{3} \mathrm{PO}_{4}\right)_{2}+4 \mathrm{H}^{+}===========3 \mathrm{Ca}^{2+}+2 \mathrm{H}_{2} \mathrm{PO}_{4^{-}}$ & 10.18 \\
$\mathrm{Ca}_{5}\left(\mathrm{PO}_{4}\right)_{3} \mathrm{OH}+7 \mathrm{H}^{+}=========5 \mathrm{Ca}^{2+}+3 \mathrm{H}_{2} \mathrm{PO}_{4^{-}}+\mathrm{H}_{2} \mathrm{O}$ & 14.46 \\
\hline
\end{tabular}

Table 3. Calculated $P b$ activity in the tested soil samples:

\begin{tabular}{lcccc}
\hline Sample No & Soil depth (cm) & Final mole Fraction & pH eq. & Log Pb $^{2+}$ \\
\hline $\mathbf{1}$ & $0-15$ & 0.040 & 6.830 & -4.9498 \\
$\mathbf{2}$ & $15-30$ & 0.100 & 7.200 & -5.26606 \\
$\mathbf{3}$ & $30-45$ & 0.080 & 7.080 & -5.26494 \\
$\mathbf{4}$ & $45-60$ & 0.040 & 7.170 & -5.63876 \\
$\mathbf{5}$ & $60-75$ & 0.040 & 7.750 & -6.7898 \\
$\mathbf{6}$ & $75-90$ & 0.040 & 7.910 & -7.1098 \\
\hline
\end{tabular}




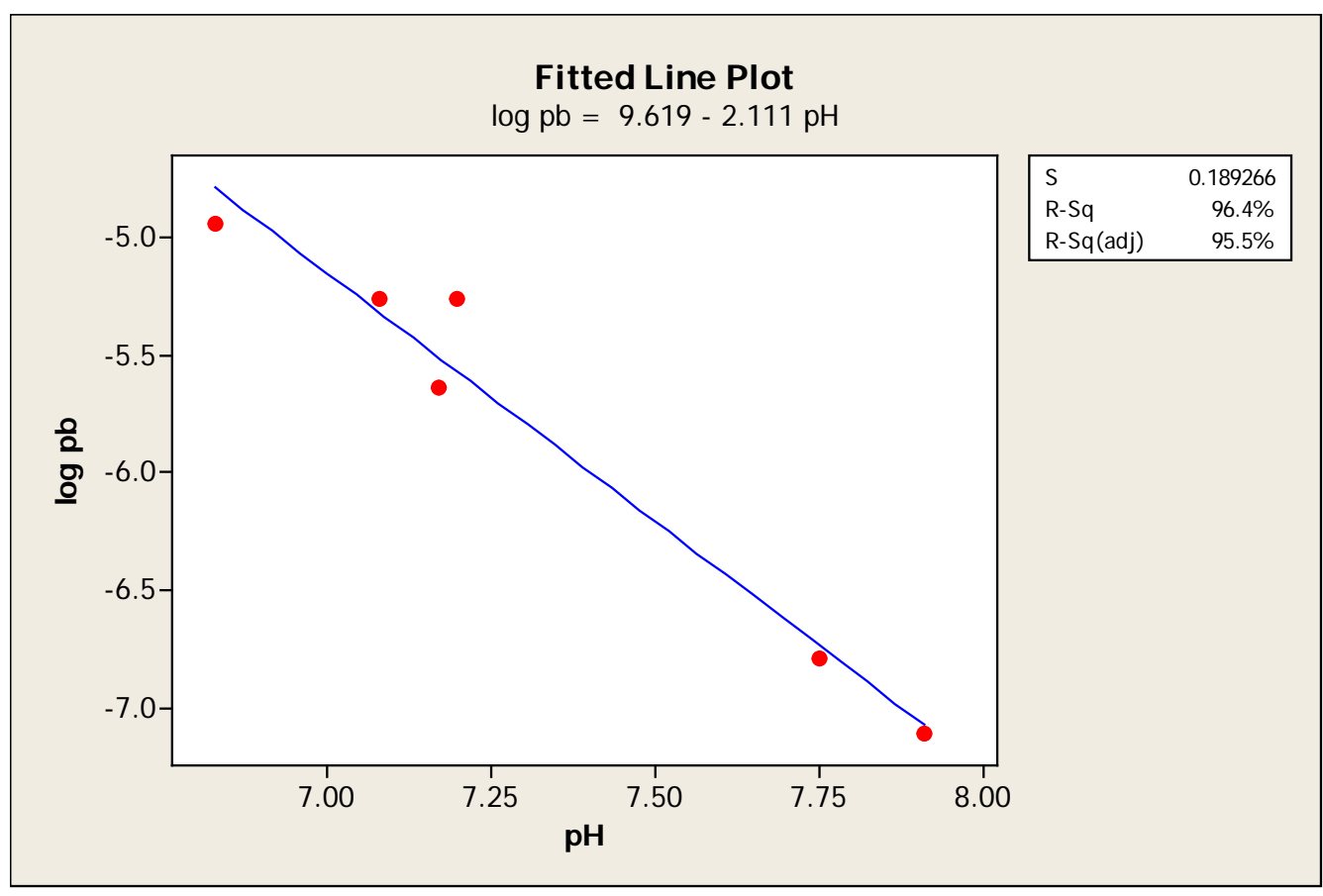

Fig. 2. Lead activities as a function of $\mathrm{pH}$ for the tested soil samples

This relationship indicates that $\mathrm{Pb}$ solubility in the soils decreased about 100 folds for each $\mathrm{pH}$ unit increase.

Lead as shown in Fig. 3 forms numerous minerals including Silicate (i,e., $\mathrm{PbSiO}_{3}$-alamosite); oxides (i.e., $\mathrm{PbO}$-massicot, $\mathrm{PbO}_{2}$-plattnerrite); carbonate (i.e., $\mathrm{PbCO}_{3}$-Cerussite, $\mathrm{Pb}_{3}\left(\mathrm{CO}_{3}\right)_{2}$ $(\mathrm{OH})_{2} \quad$ - hydroceussite, $\quad \mathrm{Pb}_{2}\left(\mathrm{CO}_{3}\right) \mathrm{Cl}-$ phosgenite); sulfate (i.e., $\mathrm{PbSO}_{4}$-anglesite); phosphate (i.e., $\mathrm{Pb}_{5}\left(\mathrm{PO}_{4}\right)_{3} \mathrm{CL}$-Pyromorphite); and halide (i.e., $\mathrm{Pb}_{2}\left(\mathrm{CO}_{3}\right) \mathrm{Cl}_{2}$ - phosgenite) minerals.

Fig. 3 shows that the solubility of $\mathrm{Pb}(\mathrm{OH})_{2}$, $\mathrm{PbCO}_{3}$ and $\mathrm{Pb}_{3}\left(\mathrm{CO}_{3}\right)_{2}(\mathrm{OH})_{2}$ are almost identical at $0.0003 \mathrm{~atm} . \mathrm{CO}_{2}$. The hydroxide $\mathrm{Pb}(\mathrm{OH})_{2}$ is considerably more stable at $\mathrm{pH} 8$ maintaining approximately $10^{-8} \mathrm{M} \mathrm{Pb}$.

Fig. 3 also shows that the solubility of $\mathrm{PbO}$ are too soluble to persist under normal conditions. For example, even at $\mathrm{pH} 8$, the $\mathrm{PbO}$ requires nearly $10^{-3} \mathrm{M} \mathrm{Pb}$ for equilibrium. Plotting the measured $\mathrm{Pb}^{2+}$ activities of the tested soils on the stability diagram as shown from Fig. 2 indicate that $\mathrm{Pb}_{2} \mathrm{SiO}_{4}$ mineral in equilibrium with $\mathrm{SiO}_{2}$ (soil ) or $\mathrm{SiO}_{2}$ (quartz) are too soluble to persist in the tested soils. Similar findings also observed with $\mathrm{PbSiO}_{3}$ mineral in equilibrium with either $\mathrm{SiO}_{2}$ (quartz) or with $\mathrm{SiO}_{2}$ (soil).

Furthermore, Pb-phosphate minerals, as shown from the figure, indicated that $\mathrm{Pb}^{+2}$ values were lower than those maintaining by $\mathrm{Pb}_{5}\left(\mathrm{PO}_{4}\right)_{3} . \mathrm{OH}$. As stated earlier by Lindsay (1979) solubility of $\mathrm{Pb}$ - phosphate depends on the level of $\mathrm{p}$ in the soil. In developing the figure, phosphate activity was fixed either by hydroxyl apatite (HA) or by tricalcium phosphate (TCP) and calcite at $0.003 a t m . \mathrm{CO}_{2}$. The solubilities of the various $\mathrm{Pb}$ phosphate minerals decrease as phosphate shifts equilibrium from HA to TCP. On the other hand, it is obvious from Fig 3 that $\mathrm{Pb}_{5}\left(\mathrm{PO}_{4}\right)_{3} \mathrm{Cl}$ is the most insoluble of lead phosphate minerals and has the capability of controlling $\mathrm{Pb}$ solubility throughout the $\mathrm{pH}$ range of most soils. In soils below $\mathrm{pH} 6, \mathrm{~Pb}$ solubility is increased as phosphate is depressed by trivalent cations such as $\mathrm{Fe}$ and $\mathrm{Al}$. These data tend to support the condition of Nriagu (1972) that $\mathrm{Pb}$ phosphate formation can serve as a sink of $\mathrm{Pb}$ in the ecosystem. 
The Figure also shows that $\mathrm{Pb}$-mixed carbonate minerals, $\mathrm{PbCO}_{3} . \mathrm{PbO}$, is too soluble to persist in the soil, it requires only $10^{-6} \mathrm{M} \mathrm{Pb}$ for equilibrium at $0.003 \mathrm{~atm} \cdot \mathrm{CO}_{2}$. On the other hand, $\mathrm{Pb}^{+2}$ values were supersaturated with respect of $\mathrm{Pb}(\mathrm{OH})_{2}, \quad \mathrm{PbCO}_{3}$ and $\mathrm{Pb}_{3}\left(\mathrm{CO}_{3}\right)_{2}(\mathrm{OH})_{2}$

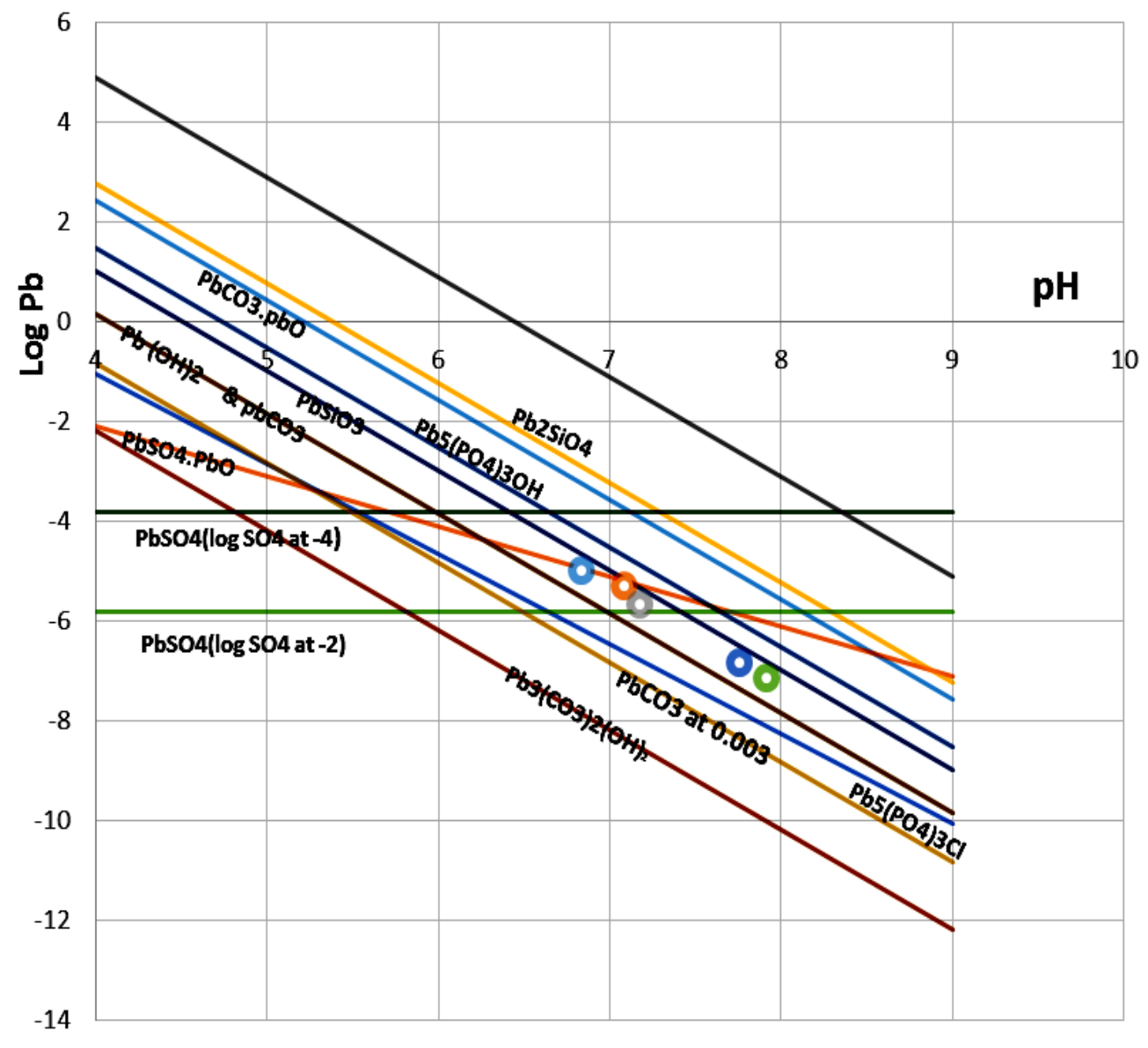

Fig. 3. Stability diagrams of various $\mathrm{Pb}$ - minerals

at 0.0003 atm. $\mathrm{CO}_{2}$ minerals. Hem (1973) concluded that in many natural surface waters the $\mathrm{Pb}^{2+}$ activity was regulated by either $\mathrm{PbCO}_{3}$ or, $\mathrm{Pb}_{3}\left(\mathrm{CO}_{3}\right)_{2}(\mathrm{OH})_{2}$. Fig. 3 also shows that with the increasing in $\mathrm{CO}_{2}$, carbonate minerals become more stable and vice versa with the decrease in reducing $\mathrm{CO}_{2}$. Under these conditions the solubility line of the carbonate minerals will shift downwards, reflecting lower equilibrium level of $\mathrm{Pb}^{2+}$ activity (i.e., $\mathrm{Pb}_{3}$ $\left(\mathrm{CO}_{3}\right)_{2}(\mathrm{OH})_{2}$ at $\left.\mathrm{CO}_{2}=0.003 \mathrm{~atm}\right)$.

Lead-sulphate minerals as shown from Fig. 3 indicate that In presence of $10^{-3} \mathrm{M} \mathrm{SO}_{4}$, mineral $\mathrm{PbSO}_{4}$ limits $\mathrm{Pb}$ at $10^{-4.79} \mathrm{M}$ and its solubility changes one log unit for each log unit change in
$\mathrm{SO}_{4}^{-2}$. The Figure also shows that in the enriched $\mathrm{Pb}$ - top soil samples, $\mathrm{Pb}^{2+}$ activity values were maintained by $\mathrm{PbSO}_{4} \cdot \mathrm{PbO}$ and $\mathrm{PbSO}_{4}\left(\log \mathrm{SO}_{4}\right.$ at -2$)$.

Santillan-Medrano and Jurinak (1975) reported that $\mathrm{Pb}$ solubility decreased in soils as $\mathrm{pH}$ increased. They added that in noncalcareous soils, solubility of $\mathrm{Pb}$ appeared to be regulated by $\mathrm{Pb}(\mathrm{OH})_{2}, \quad \mathrm{~Pb}_{3}\left(\mathrm{PO}_{4}\right)_{2}, \quad \mathrm{~Pb}_{4} \mathrm{O}\left(\mathrm{PO}_{4}\right)_{2}$, $\mathrm{Pb}_{5}\left(\mathrm{PO}_{4}\right)_{3} \mathrm{OH}$, depending on the $\mathrm{pH}$. In calcareous soils, $\mathrm{PbCO}_{3}$ also assumed importance in auto-exhausted soils. El-Gendi (1994) reported that the $\mathrm{Pb}^{2+}$ activities were within the range maintained by the formation and /or mixture of $\mathrm{PbCO}_{3}, \quad \mathrm{~Pb}_{4} \mathrm{O}\left(\mathrm{PO}_{4}\right)_{2}$, 
$\mathrm{Pb}_{5}\left(\mathrm{PO}_{4}\right)_{3} \mathrm{OH}, \mathrm{Pb}_{3}\left(\mathrm{PO}_{4}\right)_{2}$ at equilibrium with (hydroxy apatite) and $\mathrm{CaCO}_{3}$ at 0.003 atm. $\mathrm{CO}_{2}$, and $\mathrm{PbHPO}_{4}$ at equilibrium with (tricalcium phosphate) and $\mathrm{CaCO}_{3}$ at 0.003 atm. $\mathrm{CO}_{2}$. This disparity in the results emphasizes studying environmental chemistry of heavy metals as well as the importance of $\mathrm{SO}_{4}$ ligand in soil system as a tool for $\mathrm{Pb}$ remediation.

\section{REFERENCES}

Abd El-Aziz, M.A. (2014). Speciation and mobility of lead and zinc in some contaminated soils of Egypt J. Soil Sci. and Agric. Eng., Mansoura, 5 (6): 817 - 830.

Ahmed, A.E., A.S. Salman, M.S. Elmontser and M.A. Elsayed (2015). Assessment of some heavy metals pollution and bioavailability in roadside soil of Alexandria-Marsa Matruh highway, Egypt. Int. J. Ecol., (2015): 1-5.

Amacher, M.C. (1984). Determination of ionic activities in soil solutions and suspensions. Principle limitation. Soil Sci. Soc. Ame. J., 48: 519 - 524.

Alloway, B.J. (1995). Heavy metals in soils. Blackie Academic and Professional, London.

Badawy, S.H. and R.A. El-Motium (2002). Determination of free $\mathrm{Cd}$ species in pore water from soil previously treated with sewage sludge usig cation exchange resin method. Bull. Fac. Agric. Cairo Univ., 53: 141- 160.

Black ,C.A. (1965). Methods of Soil Analysis. Ame. Soc. Agron. Madison ,Wi., USA.

Candelaria, I.M., A.C. Chang and C. Amrhein (1995). Measuring cadmium ion activities in sludge amended soils. Soil Sci., 150 (3): 162175.

Chapman, H.D. and P.F. Pratt (1961). Methods of Analysis for Soils, Plant and Waters, Univ. of California, Div. Agric. Sci., USA.

Chibuike, G.U. and S.C. Obiora (2014). Heavy metal polluted soils: Effect on plants and bioremediation methods. Appl. Environ. Soil Sci., 1-12.

El-Gendi, S.A., S.H. Badawy and M.I. Helal (1997). Mobility of some heavy metal nutrients in sandy soils irrigated with sewage effluent. J. Agric. Sci. Mansoura Univ., 22: 3535-3552.
El-Gendi, S.A. (1994). Chemical equilibrium of some heavy metals. Ph.D. Thesis. Fac. Agric., Cairo Univ., Egypt.

Esawy, K.M. and G. Adel Mohamed (2016). Effect of polluted water on soil and plant contamination by heavy metals in El-Mahla El-Kobra, Egypt. Solid Earth, (7): 703- 711.

Hem, J.D. (1973). Solubility and occurrence of lead in surface water. J. Ame. Water Works Assoc., 65 : 562 -568.

Kabata-Pendias, A. and H. Pendias (1992). Trace elements in soils and plants. Boca Raton, CRC Press, Fl, USA.

Lindsay, W.L. (1979). Chemical Equilibria in Soils. John Wiley and Son, NY, USA.

Lindsay, W.L. and W.A. Norvell (1978). Development of DTPA soil test for zinc, iron, manganese and copper. Soil Sci. Ame. J., 42: 421-428.

Mota, A.M. and M.M. Correia dos Santos (1995). Trace metal speciation of labile chemical species in natural waters: electrochemical methods.In Metal speciation and bioavailability in aquatic system (Eds A. Tessier, D.R. Turner) 1995, 205-258 (Wiley: NY).

Norvell, W.A. and W.L. Lindsay (1982). Estimating of the concentration of $\mathrm{Fe}^{3+}$ and the $\left(\mathrm{fe}^{3+}\right)(\mathrm{OH}-)^{3}$ ion product from equilibria of EDTA in soil. Soil Sci. Soc. Ame. J., 46: 710-715.

Nriagu, J.O. (1972). Lead orthophosphate I: Solubility and hydrolysis of secondary lead orthophosphate. Inorg. Chem., 11 : 2499-2503.

Oyelekel, P.O., O.A.A.R. Alao Salako, O.E. Odeyemi and T.B. Abejide (2016). Assessment of some heavy metals in the surrounding soils of an automobile battery factory in Ibadan, Nigeria. Afric. J. Environ. Sci. Techn., 10 (1): 1- 8.

Santillan-Medrano, J. and J.J. Jurinak (1975). The chemistry of lead and cadmium in soil: Solid phase formation. Soil Sci. Soc. Ame. Proc., 39:851-856.

Settle, D. and C.C. Patterson (1980). Lead in Albacore: guide to lead pollution in Ame. Sci., 207: 1167-1176.

Sripathy L., R. Pratim, N.M. Ajay Kumar, S. Yashwanth, N.D. Jagadisha and K.R. 
Sharada (2015). Heavy metal contamination of soil due to vehicular traffic: A case study across Nelamangala-Dabaspet segment of national Highway No. 4. RASAYAN J. Chem., 8 (2): 232 -236.
Workman, S.M. and L.W. Lindsay (1990). Estimating divalent cadmium activities measured in arid-zone soils using competitive chelation. Soil Sci. Soc. Am. J., 54:987 993.

$$
\begin{aligned}
& \text { تقدير نشاط الرصاص في بعض الأراضى الرسوبية باستخدام طريقة الخلب التنافسى :حس }
\end{aligned}
$$

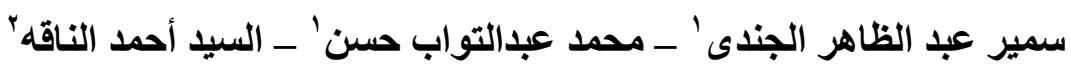

$$
\begin{aligned}
& 1 \text { ـ معهد بحوث الأر اضى و المياه و البيئة ـ مركز البحوث الزر اعية ـ مصر } \\
& \text { r ـ قسم الأر اضى ـ كلية الزر اعة ـ جامعة الزقاريق ـ مصر الإن }
\end{aligned}
$$

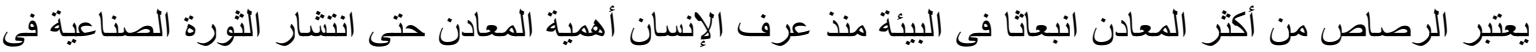

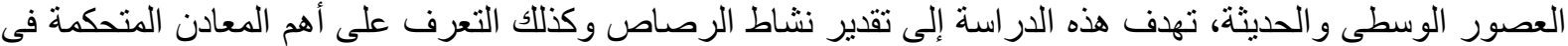

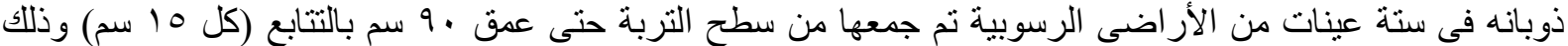

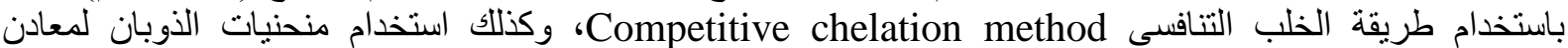

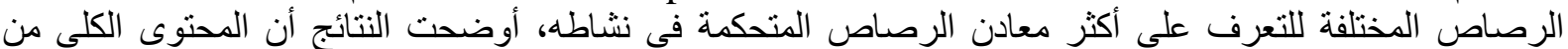

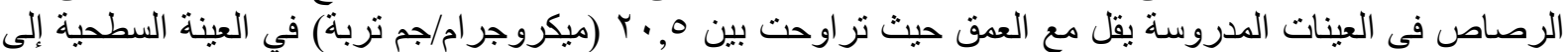

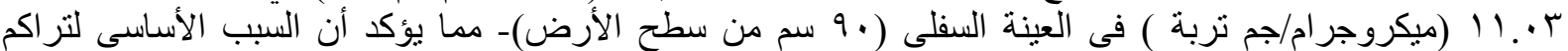

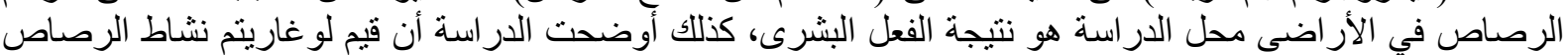

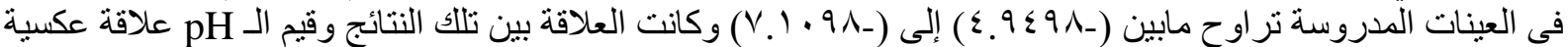

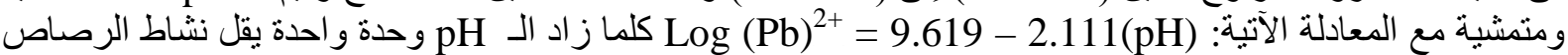

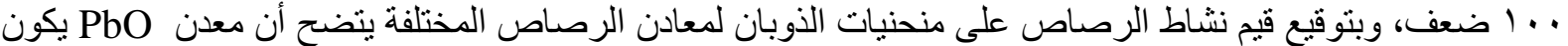
أكثر ذوبانا بحيث لا يمكن تواجده فى الظروف العادية، كذلك تدل النتائج أن معدن

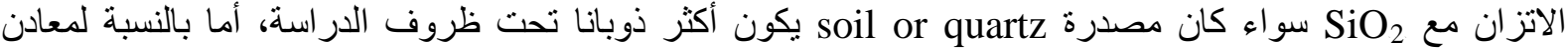

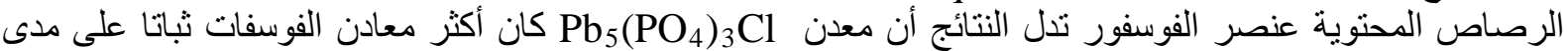

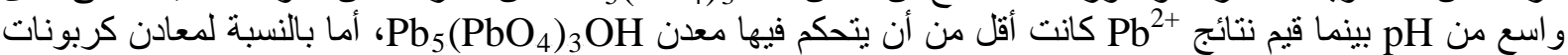

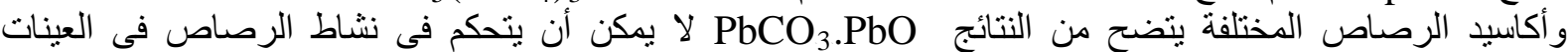

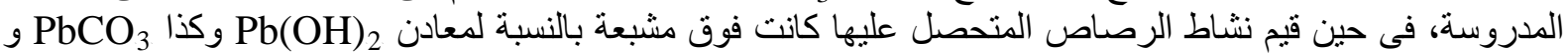
كذا النتائج على أن معدن PbSO الرصاص فى طبقات التربة السطحية، كذلك تؤكد النتائج على أهمية در اسة البيئة الكيماوية للمعادن الثقيله فى الأراضى. 